месте его нахождения, режиме работы, а также о действиях, которые необходимо совершить покупателю для получения товара, также доводить до покупателей информацию о товаре (срок годности, состав, возрастные ограничения). Совершая покупку в торговых автоматах, мы не можем получить данную информацию, так как все товары находятся в самом автомате. А в соответствии со ст. 10 Закона РФ «О защите прав потребителей» покупатель имеет право на получение вышеуказанной информации о товаре до его приобретения.

В-третьих, на наш взгляд было бы целесообразно, законодательно закрепить конкретный договор, с помощью которого будут юридически оформляться отношения для установки и обслуживания вендинг-аппаратов.

В заключении, хотелось бы отметить, что несмотря на все проблемы вендинг является одним из самых перспективных направлений развития потребительского рынка в России. С каждым годом он стремительно набирает обороты. Количество устанавливаемых торговых автоматов растет на сотни процентов в год. И если законодатель обратит внимание на все проблемы вендинга, то потребительский рынок в России получит совершенно инновационный, эффективный и комфортный для покупателей вид торговли.

$$
* * *
$$

1. Гражданский кодекс Российской Федерации (часть вторая) от 26.01.1996 N 14-Ф3 : в ред. федер. закона от 05.12.2017 N 379-Ф3 // Собрание законодательства РФ. - 1996. — № 5. — Ст. 410. — 29 янв.

2. ГОСТ Р 51303-2013. Национальный стандарт Российской Федерации. Торговля. Термины и определения : утв. Приказом Росстандарта от 28.08.2013 N 582-ст // КонсультантПлюс [Электронный ресурс]. Режим доступа: http://www.consultant.ru/document/cons_doc_LAW_167655/ (дата обращения 25.03.2018).

3. О внесении изменений в Федеральный закон «О применении контрольно-кассовой техники при осуществ-лении наличных денежных расчетов и (или) расчетов с использованием платежных карт» и отдельные за-конодательные акты Российской Федерации : федер. закон Рос. Федерации от 03.07.2016 N 290-Ф3: в ред. федер. закона от 27.11.2017 N 337-Ф3 // Российская газета. — 2016. — № 151. - 12 июл.

4. О применении контрольно-кассовой техники при осуществлении наличных денежных расчетов и (или) расчетов с использованием электронных средств платежа : федер. закон Рос. Федерации от 22.05.2003 N 54-Ф3: в ред. федер. закона от 03.07.2016 N 290-Ф3 // Российская газета. — 2003. — № 99. - 27 мая.

5. О защите прав потребителей : закон Рос. Федерации от 07.02.1992 N 2300-1 : в ред. федер. закона от 01.05.2017 N 88-Ф3 // Российская газета. — 1996. — № 8. - 16 янв.

6. Садыки, М.Р. О вендинговой торговле как инновационном ресурсе развития потребительского рынка товаров и услуг / М.Р. Садыки // РППЭ. -2013. - №4 (38). - С. 257-260.

\title{
Удалов Д.Э. \\ К вопросу о совершенствовании правового регулирования туристской деятельности
}

Государственное автономное образовательное учреждение высшего образования города Москвы «Московский государственный институт индустрии туризма имени Ю.А. Сенкевича» (Россия, Москва)

doi:10.18411/spc-20-04-2018-14

idsp: 000001:spc-20-04-2018-14

\section{Аннотация}

Статья посвящена анализу законодательных новелл, в сфере государственного регулирования туристской деятельности в Российской Федерации. Рассматриваются основные положения законодательства, определяющие порядок организации деятельности предприятий туристской индустрии.

Ключевые слова: правовое регулирование, туризм, законодательство о туризме, участники туристских отношений, туроператор, турагент. 


\section{Abstract}

The article is devoted to the analysis of legislative innovations in the sphere of state regulation of tourist activities in the Russian Federation. It focuses on discusses the main legal provisions governing the organization of activities of enterprises tourism organization.

Keywords: legal regulation, tourism, tourism legislation, tourism subjects, tour operator, travel agent.

Туристская индустрия наиболее развивающийся сектор современной экономики России. Отечественные туристские ресурсы являясь частью общемирового достояния человечества, обладают огромным потенциалом для экономики страны. На государственном уровне разработаны соответствующие программы развития как внутреннего, так и въездного туризма. Приняты нормативно-правовые акты, регулирующие права и обязанности участников туристских правоотношений, и полномочия федеральных органов государственной власти и органов государственной власти субъектов Федерации.

Основным источником правового регулирования туристских отношений является Федеральный закон от 24 ноября 1996 г. № 132-Ф3 (в ред. от 28 декабря 2016 г.) «Об основах туристской деятельности в Российской Федерации» [3]. Учитывая комплексный характер правоотношений, возникающих при реализации договора об оказании туристских услуг, к источникам правового регулирования данной сферы, также относятся: Постановление Правительства РФ от 9 октября 2015 г. «Об утверждении Правил предоставления гостиничных услуг в Российской Федерации» [7], Постановление Правительства РФ от 15 августа 1997 г. № 1036 (в ред. от 04 октября 2012 г.) «Об утверждении Правил оказания услуг общественного питания» [6], Приказ Минтранса России от 28 июня 2007 г. № 82 (в ред. от 05 октября 2017 г.) «Об утверждении Федеральных авиационных правил «Общие правила воздушных перевозок пассажиров, багажа, грузов и требования к обслуживанию пассажиров, грузоотправителей, грузополучателей» [8], и др. нормативно-правовые акты.

Комплексное правовое регулирование туристских отношений предполагает взаимодействие законодательных актов, определяющих права и обязанности обширного круга участников правоотношений, в сфере туроператорской и турагентской деятельности, деятельности по оказанию экскурсионных услуг, услуг общественного питания, услуг размещения и т.П. В следствии разнородных по своей структуре видов деятельности, названных участников в процессе реализации их прав могут возникнуть пробелы правового регулирования. Так в теории права под пробелами в правовом регулировании принято понимать - полное или частичное отсутствие в действующем законодательстве необходимых правовых норм. Пробелы в правовом регулировании возникают из-за невозможности на нормативном уровне урегулировать все многообразие жизненных ситуаций и др. Преодолеть пробелы можно с помощью правоприменительного процесса и совершенствования законодательства $[14,128]$.

К общим направлениям совершенствования правового регулирования деятельности в области туристской индустрии можно отнести следующие:

- закрепить в общей части федерального закона перечень нормативноправовых актов, являющихся источниками правового регулирования туристской и гостиничной деятельности;

- в целях совершенствования правоприменительной деятельности и учитывая юридическую силу нормативно-правовых актов, внести изменения и привести в соответствие с положениями федерального закона от 24 ноября 1996 г. № 132-Ф3 «Об основах туристской деятельности в Российской Федерации» ГОСТ Р 50690-2000 «Туристские услуги. Общие требования», принятый и введенный в действие Постановление Госстандарта России от 16 ноября 2000 г. № 295-ст [11] в части определения правового статуса туроператора в пункте 3.8 (в соответствии с абзацем 13 статьи 1, названного закона туроператором может быть только юридическое лицо). Необходимо отметить, что в соответствии с Приказом Росстандарта от 31 октября 2017 г. № 1561-ст 
«Об утверждении национального стандарта Российской Федерации» [], названный государственный стандарт утрачивает силу с 01 июня 2018 г. Проведенный анализ законодательных актов, позволяет сделать промежуточный вывод, о том, что уполномоченным государственным органам, необходимо уделять особое внимание при согласовании положений отраслевых стандартов, нормам отраслевого законодательства;

- внести дополнения в статью 1 федерального закона «Об основах туристской деятельности в Российской Федерации» в части закрепления определения экскурсии и экскурсионной деятельности.

Например, можно использовать определение экскурсии, сформулированное в ГОСТ Р53522-2009 «Туристские и экскурсионные услуги. Основные положения» [12] в пункте 3.3 - экскурсия: Услуга по удовлетворению познавательных потребностей туристов (экскурсантов), заключающаяся в коллективном (или индивидуальном) посещении и изучении определенных исторических, природных, культурных и производственных объектов в сопровождении экскурсовода, гида, гида-переводчика, продолжительностью менее 24 часов без ночевки.

Экскурсионную деятельность, можно определить, как - деятельность по организации ознакомления туристов и экскурсантов с экскурсионными объектами в месте временного пребывания, осуществляемая аккредитованным юридическим лицом или индивидуальным предпринимателем;

- включить в состав субъектов (туристов), участвующих в туристкой деятельности, инвалидов и других маломобильных лиц, а также лиц их сопровождающих (определить их правовой статус) в соответствии с федеральными законами от 28 декабря 2013 г. № 442-Ф3 (в ред. от 07 марта 2018 г.) «Об основах социального обслуживания граждан в Российской Федерации» [4] и от 24 ноября 1995 г. № 181-Ф3 (в ред. от 07 марта 2018 г.) «О социальной защите инвалидов в Российской Федерации» [2], что будет способствовать реализации принципа социального государства, провозглашенного Конституцией Российской Федерации в статье 7 [1];

- включить в состав субъектов, участвующих в туристской деятельности волонтеров (добровольцев) с определением их правового статуса;

- определить правовой статус работников, туристкой индустрии, закрепив их права и обязанности с учетом Приказа Министерства здравоохранения и социального развития РФ от 12 марта 2012 № 220н «Об утверждении Единого квалификационного справочника должностей руководителей, специалистов и служащих, раздел «Квалификационные характеристики должностей работников организаций сферы туризма» [9], а также профессиональными стандартами, в частности Приказом Министерства труда и социального развития Российской Федерации от 04 августа 2014 г. № 539н «Об утверждении профессионального стандарта «Экскурсовод (гид)» [10];

- определить понятие и виды ответственности в сфере туризма и туристкой деятельности (гражданско-правовая ответственность, административноправовая ответственность, налоговая ответственность, уголовно-правовая ответственность, дисциплинарная ответственность).

Важным этапом совершенствования правового регулирования туристских отношений является принятый 5 февраля 2018 г. федеральный закон № 16-Ф3 «О внесении изменений в Федеральный закон «Об основах туристской деятельности в Российской Федерации» и Кодекс Российской Федерации об административных правонарушениях в целях совершенствования правового регулирования предоставления гостиничных услуг и классификации объектов туристской индустрии» [5], согласно положениям которого в перечень субъектов туристских отношений включены средства размещения и гостиницы, а также установлена ответственность за нарушение законодательства в профессиональной деятельности. 
На основании проанализированного материала можно сделать вывод о необходимости дальнейшего совершенствования правового регулирования деятельности в туристской индустрии. В целях соблюдения прав всех участников туристских отношений.

$$
\text { *** }
$$

1. Конституция Российской Федерации // Собрании законодательства РФ. - 2014. - № 15. - Ст. 1691.

2. Федеральный закон от 24 ноября 1995 г. № 181-ФЗ (в ред. от 07 марта 2018 г.) «О социальной защите инвалидов в Российской Федерации» // Собрание законодательства РФ. - 1995. - № 48. - Ст. 4563.

3. Федеральный закон от 24 ноября 1996 г. № 132-Ф3 (в ред. от 28 декабря 2016 г.) «Об основах туристской деятельности в Российской Федерации» // Собрание законодательства РФ. - 1996. - № 49. - Ст. 5491.

4. Федеральный закон от 28 декабря 2013 г. № 442-Ф3 (в ред. от 07 марта 2018 г.) «Об основах социального обслуживания граждан в Российской Федерации» // Собрание законодательства РФ. 2013. - № 52 (часть I). - Ст. 7007.

5. Федеральный закон от 5 февраля 2018 г. № 16-Ф3 «О внесении изменений в Федеральный закон «Об основах туристской деятельности в Российской Федерации» и Кодекс Российской Федерации об административных правонарушениях в целях совершенствования правового регулирования предоставления гостиничных услуг и классификации объектов туристской индустрии» // Собрание законодательства РФ. - 2018. - № 7. - Ст. 976.

6. Постановление Правительства РФ от 15 августа 1997 г. № 1036 (в ред. от 04 октября 2012 г.) «Об утверждении Правил оказания услуг общественного питания» // Собрание законодательства РФ. 1997. - № 34. - Ст. 3980.

7. Постановление Правительства РФ от 9 октября 2015 г. «Об утверждении Правил предоставления гостиничных услуг в Российской Федерации» // Собрание законодательства РФ. - 2015. - № 42. Ст. 5796.

8. Приказ Минтранса России от 28 июня 2007 г. № 82 (в ред. от 05 октября 2017 г.) «Об утверждении Федеральных авиационных правил «Общие правила воздушных перевозок пассажиров, багажа, грузов и требования к обслуживанию пассажиров, грузоотправителей, грузополучателей» // Российская газета. - 2007. - № 225.

9. Приказ Министерства здравоохранения и социального развития РФ от 12 марта 2012 № 220н «Об утверждении Единого квалификационного справочника должностей руководителей, специалистов и служащих, раздел «Квалификационные характеристики должностей работников организаций сферы туризма» // Бюллетень нормативных актов федеральных органов исполнительной власти. - 2012. № 29.

10. Приказ Министерства труда и социальной защиты РФ от 04 августа 2014 г. № 539н (в ред. от 12 декабря 2016 г.) «Об утверждении профессионального стандарта «Экскурсовод (гид)» // Бюллетень нормативных актов федеральных органов исполнительной власти. - 2015. - № 3.

11. «ГОСТ Р 50690-2000. Государственный стандарт Российской Федерации. Туристские услуги. Общие требования» (принят и введен в действие Постановлением Госстандарта РФ от 16 ноября 2000 г. № 295-ст) // М.: ИПК Издательство стандартов, 2001 г.

12. «ГОСТ Р 53522-2009. Национальный стандарт Российской Федерации. Туристские и экскурсионные услуги. Основные положения» (утв. и введен в действие Приказом Ростехрегулирования от 15 декабря 2009 г. № 772-ст) // М.: Стандартинформ, 2010 г.

13. Приказ Росстандарта от 31 октября 2017 г. № 1561-ст «Об утверждении национального стандарта Российской Федерации» // [Электронный ресурс]. Режим доступа: http://www.consultant.ru/cons/cgi/online, (дата обращения: 17.04.2018).

14. Юридический энциклопедический словарь / под ред. А.В. Малько. - 2-е изд. - Москва: Проспект, 2017. $-1136 \mathrm{c}$. 